\title{
Control of gonadotrophin release in Scottish Blackface and Finnish Landrace ewes during seasonal anoestrus
}

\author{
R. Webb, G. Baxter, R. D. Preece*, R. B. Land and A. J. Springbett \\ A.F.R.C. Animal Breeding Research Organisation, Dryden Laboratory, Roslin, \\ Midlothian EH25 9PS, U.K.
}

\begin{abstract}
Summary. The patterns of LH and FSH secretion were measured in 4 experimental groups of Finnish Landrace and Scottish Blackface ewes: long-term (18 months) ovariectomized ewes (Group 1), long-term ovariectomized ewes with an oestradiol implant, which has been shown to produce peripheral levels of $\sim 5 \mathrm{pg} / \mathrm{ml}$ (Group 2), long-term ovariectomized ewes with an oestradiol implant for 18 months which was subsequently removed (surgery on Day 0) (Group 3) and short-term ovariectomized ewes (surgery on Day 0) (Group 4). LH and FSH concentrations were monitored in all groups at approximately weekly intervals, before and after Day 0. Finnish Landrace ewes in Groups 1, 2 and 3 had significantly higher mean FSH concentrations than did Scottish Blackface ewes $(P<0.01)$. FSH and LH concentrations increased significantly in Groups 3 and 4, but values in Group 4 were significantly lower $(P<$ $0.01)$ than those in Group 1 ewes even up to 30 days after ovariectomy. In Group 3, LH concentrations increased to levels similar to those in Group 1. The pattern of $\mathrm{LH}$ release was, however, significantly different, with a lower LH pulse frequency $(P<$ $0.05)$, but higher pulse amplitude $(P<0.05)$. This difference was maintained at least until 28 days after implant removal.

We suggest that removal of negative feedback by ovariectomy demonstrates an underlying breed difference in the pattern of FSH secretion and that ovarian factors other than oestradiol are also involved in the negative-feedback control of hypothalamic/pituitary gland function. Furthermore, negative-feedback effects can be maintained for long periods, at least 28 days, after ovariectomy or oestradiol implant removal.
\end{abstract}

\section{Introduction}

In sheep gonadotrophic hormones play a major role in the control of follicular growth and maturation (see reviews by Baird \& McNeilly, 1981; Webb \& Gauld, 1984). The possibility that different ovulation rates in breeds of sheep may be causally related to peripheral gonadotrophin concentrations has been studied extensively. However, the general consensus from these studies is that peripheral hormone concentrations do not fully explain the difference in ovulation rate found between breeds of sheep (see review by Bindon \& Piper, 1982; Land, Atkins \& Roberts, 1983). This conclusion is not surprising when the dynamic relationships between the hypothalamus, pituitary gland and ovary are considered. These relationships can alter depending on a number of factors, including stage of the oestrous cycle, time of year and nutritional status.

It has been proposed that a lower sensitivity of the hypothalamus/pituitary gland to the 
negative-feedback effect of gonadal hormones enables breeds with higher ovulation rates to tolerate higher concentrations of ovarian hormones before there is a reduction in the release of gonadotrophins (Land, 1976; Land, Wheeler \& Carr, 1976). Hence there could be a significant difference in ovulation rate without significant changes in peripheral gonadotrophin concentrations.

Mature Graafian follicles are present at all stages of the reproductive cycle, with the breeds of sheep with higher ovulation rates having significantly more mature follicles, even during seasonal anoestrus (Webb \& Gauld, 1984). It has therefore been postulated that the mechanism controlling the number of mature Graafian follicles is present during seasonal anoestrus as well as during both the luteal and follicular phases of the oestrous cycle. The main aim of the present study was to investigate the control of gonadotrophin release in two breeds of sheep with different ovulation rates, Finnish Landrace (ovulation rate $\sim 3$ ) and Scottish Blackface (ovulation rate $\sim 1 \cdot 5$ ), during seasonal anoestrus, a period when there is less variation in gonadotrophic hormone concentrations. The peripheral patterns of gonadotrophin concentrations were measured both before and after ovariectomy or removal of an oestradiol implant from long-term ovariectomized ewes.

\section{Materials and Methods}

Animals. The 28 Finnish Landrace (mean \pm s.e.m. bodyweight $=53.6 \pm 1 \cdot 2 \mathrm{~kg}$ ) and 22 Scottish Blackface (mean \pm s.e.m. bodyweight $=57.3 \pm 2.3 \mathrm{~kg}$ ) ewes were kept on grass with supplementary feed as dictated by normal husbandry.

Experimental design. There were 4 experimental groups per breed: Group 1, long-term ovariectomized ewes (6 Finnish Landrace; 6 Scottish Blackface); Group 2, long-term ovariectomized ewes with an oestradiol implant (6 Finnish Landrace; 6 Scottish Blackface); Group 3, longterm ovariectomized ewes with an oestradiol implant which was subsequently removed (7 Finnish Landrace; 4 Scottish Blackface); and Group 4, short-term ovariectomized ewes (9 Finnish Landrace; 7 Scottish Blackface).

Ewes in Groups 1, 2 and 3 were ovariectomized during February. In Groups 2 and 3 Silastic (Dow Corning, Midland, MI, U.S.A.) implants containing oestradiol, as described by Karsch et al. (1973), were inserted 1 month earlier. Although not measured in this experiment, the size of the oestradiol implant used has been demonstrated to produce mean peripheral oestradiol concentrations of $5.5 \pm 0.4 \mathrm{pg} / \mathrm{ml}(\mathrm{N}=7 ; \mathrm{R}$. Webb \& $\mathrm{G}$. Baxter, unpublished data) in ovariectomized Welsh Mountain ewes, as reported by Legan, Karsch \& Foster (1977) in different breeds of cross-breed ewes. This type of implant also maintains this level of secretion for at least 12 months (Legan et al., 1977). Implants or ovaries were removed from sheep in Groups 3 and 4 respectively in June, about 18 months after ovariectomy (Groups 1,2 and 3). There were no corpora lutea in the ovaries at the time of ovariectomy, indicating that all the sheep were seasonally anoestrous. Five samples of blood were collected from all animals at intervals of $100 \mathrm{~min}$, and from 2 ewes of each group and breed at intervals of $20 \mathrm{~min}$, for $400 \mathrm{~min}$ duration, sampling on 6 occasions. The first sampling period was 1-3 days before implant removal or ovariectomy in Groups 3 and 4 respectively, the second sampling period the day after this treatment and then the last 4 sampling periods at weekly intervals after treatment. Plasma was stored at $-20^{\circ} \mathrm{C}$ until assayed.

Hormone assays. Concentrations of $\mathrm{LH}$ in peripheral plasma were determined in duplicate using a modified radioimmunoassay described previously (Martensz, Baird, Scaramuzzi \& Van Look, 1976; Land, Carr, McNeilly \& Preece, 1980). All samples from a single ewe were measured in the same assay. A purified ovine LH preparation (M4; $2.9 \times \mathrm{NIH}-\mathrm{LH}-\mathrm{S} 1)$ was used for labelling and the results are expressed in terms of NIH-LH-S18. The assay and the results were computed by the A.B.R.O. Radioimmunoassay Program package based on the method of Rodbard \& Lewald (1970). The rabbit anti-ovine LH serum bound $33.6 \pm 2.2 \%$ (14 assays) of the label at a final 
dilution of $1: 800000$. The slope of the standard curve was $-1.06 \pm 0.01(n=14)$. Assay sensitivity was $0.4 \pm 0.002 \mathrm{ng} / \mathrm{ml}(n=11)$. The antiserum showed $<0.05 \%$ inhibition when tested against ovine hormone preparations NIH-P-S9, NIH-GH-S10, NIH-FSH-S9 and $1 \cdot 1 \%$ inhibition with NIH-TSH-S6. There was, however, no increase in mean LH concentrations in a ram treated with TRF.

Inhibition curves for a number of ovine plasma samples of dilutions ranging from $1: 2.5$ to $1: 50$ were parallel to the LH standard curve. Also, plasma samples from each breed were found to be parallel with the standard curve. Accuracy was assessed by comparing standard curves for LH in buffer or $200 \mu \mathrm{l}$ ram plasma. The curves were superimposable. The inter-assay coefficients of variation in 18 assays, using three standard quality control samples with mean concentrations of $0.74 \pm 0.03,9.7 \pm 0.2$ and $11.8 \pm 0.2 \mathrm{ng} / \mathrm{ml}$, were $18.7,6.4$ and $8.0 \%$ respectively. The intra-assay coefficient of variation was $4.4 \%(n=10)$.

Concentrations of FSH in peripheral plasma were determined in duplicate using the modified radioimmunoassay described by McNeilly, McNeilly, Walton \& Cunningham (1976). All samples from a single ewe were measured in the same assay. A purified rat preparation (NIAMDD-FSH-I5) was used for labelling and the results are expressed in terms of NIH-FSH-S9. The assay and the results were calculated as for LH. The rabbit anti-human FSH (M91) bound $22.0 \pm 0.9 \%(n=8)$ of the label at a final dilution of $1: 40000$. The slope of the standard curve was $-0.96 \pm 0.01(n=8)$. Sensitivity was $24.2 \pm 5.9 \mathrm{ng} / \mathrm{ml}(n=8)$. Inhibition curves for 9 plasma samples of sheep at dilutions from $1: 4$ to $1: 16$ were parallel to the FSH standard curve. Also, plasma samples from ewes of each breed were found to be parallel with the standard curve. The inter-assay coefficients of variation in 8 assays using three standard quality-control samples with mean concentrations of 36.6 $\pm 3.33,685.3 \pm 12.7$ and $1475.0 \pm 39.1 \mathrm{ng} / \mathrm{ml}$, were $17.5,4.9$ and $7.0 \%$ respectively. The intraassay coefficient of variation was $8 \cdot 8 \%(n=9)$.

Statistical analyses. Unless otherwise indicated all the data have been transformed to natural logarithms to normalize the distribution before analysis of variance. Significant differences between groups were analysed using Scheffe's multiple comparison test (Scheffé, 1959) at the 5\% level. The antilog values of the transformed data are presented as geometric means.

A rise in $\mathrm{LH}$ was considered to be a pulse if the pattern of secretion complied with the following criteria. A nadir is defined as a minimum turning point, the immediately adjacent previous and following values of which are greater than itself. A peak was defined as a maximum turning point, the immediately adjacent previous and following values of which are less than itself. The lower $95 \%$ confidence limit of the peak value had to be greater in value than twice the difference between the previous nadir and its upper $95 \%$ confidence limit added to the value of the nadir. The amplitude of all such pulses was calculated as the potency estimate for the peak value less the potency estimate of the previous nadir value.

\section{Results}

\section{Mean peripheral plasma $\mathrm{LH}$ concentrations}

There was no significant difference between the two breeds in mean peripheral LH concentrations over all treatments (Table 1). The data have therefore been presented as an overall mean for the two breeds of sheep. The ewes in Group 1 had consistently higher LH concentrations $(P<0.05)$ than did those in Group 2 (Text-fig. 1). There was no significant difference between Groups 2, 3 and 4 before ovariectomy or implant removal. Ovariectomy (Group 4) or removal of an oestradiol implant (Group 3) was followed by an increase in mean LH levels, although levels in Group 4 increased significantly faster $(P<0.05)$ during the next $2-3$ weeks than did those in Group 3 ewes. Nevertheless, LH concentrations in Group 3, by Day 22 after removal of the implant, were the same as those in Group 1. LH concentrations in Group 4 ewes plateaued at a significantly lower level $(P<0.01)$ by Day 15 . The significant $(P<0.01)$ sheep $\times$ occasion 
Table 1. Summary of the analysis of variance in the overall mean $\mathrm{LH}$ concentrations in Finnish Landrace and Scottish Blackface ewes given various treatments during seasonal anoestrus (see 'Materials and Methods')

\begin{tabular}{lrrc}
\hline \multicolumn{1}{c}{ Source of variation } & d.f. & m.s. & Significance \\
\hline Breed & 1 & 0.41 & N.S. \\
Treatment & 3 & 417.17 & - \\
Occasion & 5 & 66.90 & - \\
Treatment $\times$ Occasion & 15 & 22.45 & $P<0.01$ \\
Sheep within breed $\times$ Treatment & 41 & 1.81 & $P<0.01$ \\
Occasion $\times$ Sheep & 205 & 0.48 & $P<0.01$ \\
Error & 176 & 0.21 & \\
\hline
\end{tabular}

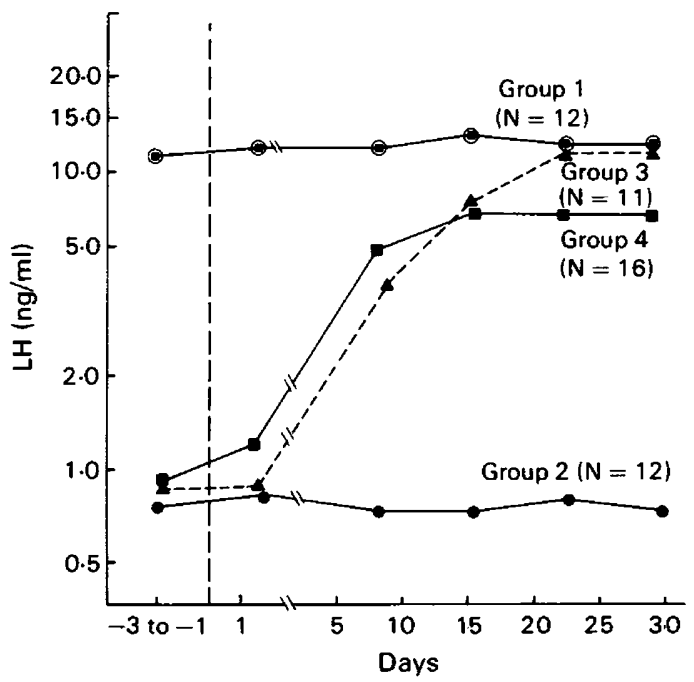

Text-fig. 1. Geometric mean LH concentrations in ewes $(N=12)$ in Group 1 (long-term ovariectomy), Group $2(\mathrm{~N}=12)$ (long-term ovariectomy ewes plus oestradiol implant), Group $3(\mathrm{~N}=11)$ (long-term ovariectomy and removal of oestradiol implant) and Group $4(\mathrm{~N}=16)$ (short-term ovariectomy). The broken vertical line indicates the time (Day 0 ) of implant removal (Group 3) or ovariectomy (Group 4); $N=$ the number of animals. The hormone concentrations are expressed on a natural logarithm scale.

interaction (Table 1) reflects the greater variation in mean LH concentrations in sampling periods 2-5 (Days 1-22) as different sheep responded at different rates. By period 6 LH concentrations appeared to have stabilized.

\section{LH pulse frequency and pulse amplitude}

There was no significant difference between the two breeds in either LH pulse frequency or amplitude. The data have therefore again been presented as overall means for the two breeds (Textfig. 2). The analysis has also been confined to data for sampling periods 3-6 and for Groups 1,3 and 4 , because the sheep in Group 2 produced no pulses on $66 \%$ of the sampling periods and never produced more than 2 pulses on any one occasion, as expected (Goodman, Bittman, Foster \& Karsch, 1982). There were also similar responses for Groups 3 and 4 on sampling occasions 1 and 2 , 



Text-fig. 2. Mean LH pulse frequency (a) and geometric mean LH pulse amplitude (b) in ewes in Group 1 (long-term ovariectomy), Group 3 (long-term ovariectomy and removal of oestradiol implant) and Group 4 (short-term ovariectomy). There were 4 animals per group, each animal being sampled for 400 min at 20 -min intervals on each occasion (Day 0 being the time of oestradiol implant removal or ovariectomy in Groups 3 and 4 respectively). The LH concentrations for pulse amplitude are expressed on a natural logarithm scale.

except for one ewe in Group 4 which exhibited 5 LH pulses during sampling period 2, with a mean pulse amplitude of $3.3 \pm 1.2 \mathrm{ng} / \mathrm{ml}$.

Pulse frequency. The data were not transformed before the analysis of variation (Table 2). The ewes in Group 1 had a significantly higher $(P<0.05)$ number of LH pulses per sampling period $(400 \mathrm{~min}$ ) than did those in Group 3 (Text-fig. 2a). Values for ewes in Group 4 were between those of Groups 1 and 3, but were not significantly different. However, pulse frequency appeared to be increasing throughout the experimental period in Group 3 ewes.

Pulse amplitude. The data were transformed to natural logarithms before analysis of variation (Table 2). There was large variation between sheep of the same breed and on the same treatment, as indicated by the significant $(P<0.05)$ animal within breed $\times$ treatment interaction. Despite this variability the ewes in Group 3 had LH pulses of significantly greater amplitude $(P<0.05)$ than did those in the other groups, except during sampling period 3 (Day 8) when values for Group 4 ewes were not significantly different (Text-fig. 2b). There was no significant difference between the LH pulse amplitude for ewes in Groups 2 and 4.

Table 2. Summary of the analysis of variance in the LH pulse frequency and LH pulse amplitude in Finnish Landrace and Scottish Blackface ewes given various treatments during seasonal anoestrus (see 'Materials and Methods')

\begin{tabular}{|c|c|c|c|c|}
\hline \multirow[b]{2}{*}{ Source of variation } & \multicolumn{2}{|c|}{ Pulse frequency } & \multicolumn{2}{|c|}{ Pulse amplitude } \\
\hline & d.f. & m.s. & d.f. & m.s. \\
\hline $\begin{array}{l}\text { Breed } \\
\text { Treatment } \\
\text { Occasion } \\
\text { Treatment } \times \text { Occasion }\end{array}$ & $\begin{array}{l}1 \\
2 \\
3 \\
6\end{array}$ & $\begin{array}{l}2 \cdot 08 \\
16 \cdot 53^{* *} \\
1 \cdot 03 \\
1 \cdot 30\end{array}$ & $\begin{array}{l}1 \\
2 \\
3 \\
6\end{array}$ & $\begin{array}{r}1.91 \\
18.21 \\
0.96 \\
1.61^{*}\end{array}$ \\
\hline $\begin{array}{l}\text { Animal within breed } \times \text { Treatment } \\
\text { Animal } \times \text { Occasion }\end{array}$ & & - & $\begin{array}{r}6 \\
18\end{array}$ & $\begin{array}{l}3 \cdot 78^{*} \\
0.42^{*}\end{array}$ \\
\hline Error & 18 & 0.68 & 190 & $0 \cdot 24$ \\
\hline
\end{tabular}

${ }^{*} P<0.05 ;{ }^{* *} P<0.01$. 
The data indicate an inverse relationship between $\mathrm{LH}$ pulse frequency and $\mathrm{LH}$ pulse amplitude, with the ewes in Group 1 having the highest pulse frequency, but the lowest pulse amplitude. In comparison, the ewes in Group 3 had the lowest pulse frequency, but the highest pulse amplitude. Furthermore, these differences appeared to be maintained to the end of the sampling periods.

\section{Peripheral plasma FSH concentrations}

There was a significant difference $(P<0.01$; Table 3$)$ between the two breeds in mean peripheral FSH concentrations. The results of each treatment for each breed have therefore been presented separately (Text-fig. 3). Finnish Landrace ewes had significantly higher $(P<0.01)$ FSH

Table 3. Summary of the analysis of variance in mean FSH concentrations in Finnish Landrace and Scottish Blackface ewes given various treatments during seasonal anoestrus (see 'Materials and Methods')

\begin{tabular}{lrrc}
\hline \multicolumn{1}{c}{ Source of variation } & d.f. & m.s. & Significance \\
\hline Breed & 1 & 9.49 & $P<0.01$ \\
Treatment & 3 & 484.51 & - \\
Occasion & 5 & 63.49 & - \\
Breed $\times$ Treatment & 3 & 3.71 & N.S. \\
Treatment $\times$ Occasion & 15 & 19.71 & $P<0.01$ \\
Sheep within breed $\times$ Treatment & 37 & 1.70 & $P<0.01$ \\
Sheep $\times$ Occasion & 220 & 0.19 & $P<0.01$ \\
Residual factor & 1176 & 0.072 & \\
\hline
\end{tabular}

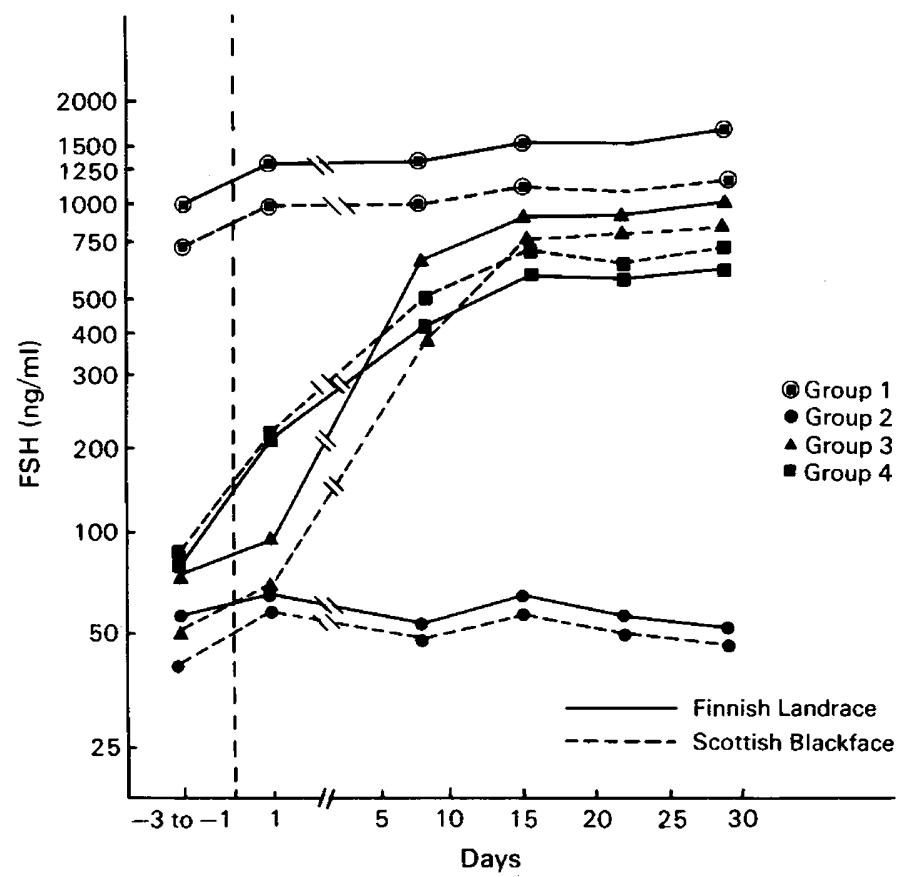

Text-fig. 3. Geometric mean FSH concentrations in 6-9 Finnish Landrace and 4-7 Scottish Blackface ewes in Group 1 (long-term ovariectomy), Group 2 (long-term ovariectomy plus an oestradiol implant), Group 3 (long-term ovariectomy and removal of oestradiol implant) and Group 4 (short-term ovariectomy). The vertical broken line indicates the time (Day 0 ) of implant removal (Group 3) or ovariectomy (Group 4). The hormonal concentrations are expressed on a natural logarithm scale. 
concentrations than did Scottish Blackface ewes in Groups 1, 2 and 3. Conversely, Scottish Blackface ewes in Group 4 had higher FSH levels than did Finnish Landrace ewes in Group 4, although this difference did not reach significance. Unlike the LH levels, the mean FSH concentrations in Group 3 ewes did not reach the same values obtained in Group 1 ewes. However, the ewes in Group 1 did have significantly $(P<0.05)$ higher FSH concentrations than did those in Group 4 throughout the experiment.'FSH concentrations in Group 2 ewes were significantly lower $(P<0.05)$ than those in the other three groups from sampling period 3 (Day 8 ) onwards. During period 1 the values for Groups 2 and 3 were not significantly different. When the values for these two groups during period 1 (Days -3 to -1 ) were combined and compared to those of Group 4 ewes, they were significantly lower $(P<0.05)$. In both breeds there was also an indication of an upward trend in mean FSH levels during the sampling period in Group 1 ewes but this increase was not significant.

\section{Discussion}

The results demonstrate that there was a significant difference between the ewes of the Scottish Blackface and Finnish Landrace breeds in mean FSH concentrations in the long-term ovariectomized groups (Text-fig. 3; Table 3), but not in mean LH concentrations (Text-fig. 1; Table 1). The treatments also had a significant effect on the pattern of LH and FSH release. The treatment effects support a previous conclusion, using different breeds of sheep, that physiological concentrations of oestradiol in ovariectomized ewes inhibit the release of both LH (Legan et al., 1977; Goodman, Legan, Ryan, Foster \& Karsch, 1981a; Platt, Foster, Tarnavsky \& Reeves, 1983) and FSH (Legan \& Karsch, 1980; Platt et al., 1983) during seasonal anoestrus. The results extend these findings by demonstrating that, as for LH (Goodman et al., 1981a), there is also a significant increase in FSH concentrations after ovariectomy or removal of an oestradiol implant from ovariectomized ewes.

Although studies of peripheral gonadotrophin concentrations do not fully explain the differences in ovulation rate between breeds, recent evidence has implicated FSH in the control of the number of developing follicles. Infusion of ovine FSH, from 24 before injection with PGF- $2 \alpha$ results in approximately a 6-fold increase in ovulation rate (D. T. Baird, A. S. McNeilly, J. Wallace \& R. Webb, unpublished data). Also, ewes with twin lambs have higher FSH concentrations from 8 to 3 days before ovulation than do those with singletons (Davis, Brien, Findlay \& Cumming, 1981). Lahlou-Kassi, Schams \& Glatzel (1984) have demonstrated that FSH concentrations were higher in the prolific D'Man than in Timahdite ewes in contrast to the study of Webb \& England (1982) using Suffolk and Finnish Landrace sheep. The results from the present study do indicate that there is an underlying breed difference in hypothalamic/pituitary gland function after the removal of an oestradiol implant, with ewes of the breed with the higher ovulation rate secreting significantly higher levels of FSH after long-term ovariectomy. Whether this underlying effect is important in intact animals requires further investigation as this difference was not apparent in the short-term ovariectomized ewes. The Scottish Blackface ewes appeared to have higher levels of FSH than did the Finnish Landrace ewes. This may be due to greater ovarian negative feedback produced by increased levels of oestradiol in the higher ovulation rate breed, as occurs during the breeding season (Cahill et al., 1981).

In the present study, after ovariectomy, the Finnish Landrace ewes had higher FSH levels than did the Scottish Blackface ewes, despite having an oestradiol implant of the same size supporting further the hypothesis of different hypothalamic/pituitary gland sensitivity in the two breeds. Also the difference in FSH concentrations between the breeds after short-term ovariectomy increased by 10 -fold from sampling occasion one to sampling occasion six. One possible reason for the increased rate of FSH secretion by the Scottish Blackface ewes compared to the Finnish Landrace ewes may be related to differences in hypothalamic sensitivity to ovarian feedback, with a more rapid increase in FSH concentrations in the more sensitive breeds. 
The finding that during period 1 the long-term ovariectomized ewes with an oestradiol implant had significantly lower FSH concentrations than did short-term ovariectomized ewes does not support the conclusion of Goodman, Pickover \& Karsch (1981b) that an ovarian hormone other than oestradiol contributes to the feedback control of FSH secretion. However, major differences exist between these two studies which may account for the lack of agreement. Firstly, the study of Goodman et al. (1981b) was carried out in the breeding season. Secondly, although the oestradiol implants were inserted before ovariectomy in the present study, these were long-term ovariectomized ewes and there is evidence to suggest that the response of the neuroendocrine axis to steroid inhibition does change after ovariectomy (Brown, Cumming, Goding \& Hearnshaw, 1972; Karsch, Legan, Hauger \& Foster, 1977). Finally, the oestradiol implants used in this study provide plasma concentrations of 4-5 $\mathrm{pg} / \mathrm{ml}$ whereas intact ewes during seasonal anoestrus have peripheral concentrations of $1-3 \mathrm{pg} / \mathrm{ml}$ (Legan \& Karsch, 1979) which is released in a pulsatile fashion (Scaramuzzi \& Baird, 1977). Sheep are more sensitive to oestradiol during seasonal anoestrus and therefore this increased sensitivity may override other ovarian factors that appear to play a role in controlling FSH release (Miller, Critser \& Ginther, 1982; Cummins, O'Shea, Bindon, Lee \& Findlay, 1983).

Although oestradiol- $17 \beta$ appears to be the major hormone controlling release of gonadotrophins during seasonal anoestrus in sheep, another ovarian factor(s) appears to influence pituitary gland function, as indicated by the response of LH and FSH after removal of an oestradiol implant or ovariectomy. Despite the rise in LH concentrations being significantly slower after implant removal than after ovariectomy, probably due to a lower pituitary content of LH resulting from the oestradiol treatment (Wright, Findlay \& Anderson, 1981) the mean LH levels in both groups of long-term ovariectomized ewes were significantly higher than in the short-term ovariectomized ewes by Day 21 (see Text-fig. 1). The same trend was also noted for FSH (see Text-fig. 3), although the differences did not reach significance.

The LH pulse frequency and amplitude in the long-term and short-term ovariectomized ewes were similar to previously reported values (Goodman, Bittman, Foster \& Karsch, 1982; Wright, Stelmasiak \& Anderson, 1983). However, the initial increase in peripheral LH concentrations, LH pulse frequency and LH pulse amplitude observed by Wright et al. (1983) following ovariectomy were not seen in this study. The significant differences in LH pulse frequency and amplitude between the long-term ovariectomized groups (Text-fig. 2) supports a previous hypothesis (Goodman et al., 1982) that during seasonal anoestrus oestradiol can suppress LH pulse frequency with a corresponding increase in LH pulse amplitude. The conclusion that oestradiol acts on the LHRH pulse generating system is further supported by reports that a pulse of LH is preceded or accompanied by a pulse of LHRH from the hypothalamus (Clarke \& Cummins, 1982; Levine, Pan, Ramirez \& Jackson, 1982). Despite the significant effect of breed on FSH there appeared to be no difference in the pattern of LH release. The reason for this is not known, although differential effects of LHRH immunoneutralization on LH and FSH secretion in the ewe have been demonstrated (Fraser \& McNeilly, 1983).

The residual modulating effect of oestradiol and/or other ovarian factors on pituitary gland function and gonadotrophin secretion appeared to remain throughout the sampling period (Textfig. 2). It would seem that the effect of negative feedback on gonadotrophin release can exist for relatively long periods, at least 4 weeks, after removal of the source of feedback. A more rapid change in the pattern of release of gonadotrophins may therefore require a direct stimulation at the hypothalamic and/or pituitary gland.

Studies of rats have demonstrated that serum LH levels and pituitary gland LH concentrations can increase over at least 90 days after ovariectomy (Garner \& Blake, 1981). Furthermore, increases in LH concentrations were coupled with morphological changes in the pituitary gland. Therefore, the significant difference in mean LH and FSH concentrations, between long- and short-term ovariectomized ewes, as well as being related to hypothalamic control, do not preclude changes in pituitary morphology that can occur even in the presence of an oestradiol implant. 
In conclusion, there appears to be an underlying breed difference in hypothalamic and/or pituitary gland function and in particular in FSH secretion. Whether this explains the differences in ovulation rate between the breeds still remains to be determined. This study has demonstrated that oestradiol alone cannot account for all the changes and that other ovarian factors have an effect on the secretion of gonadotrophins. Furthermore, these effects can be maintained for long periods after removal of negative feedback.

We thank Miss M. Fordyce and the farm staff for excellent technical assistance; Mrs J. Cherrie for preparing the manuscript and $\mathrm{Mr} \mathrm{C}$. Manson for art work; Dr I. K. Gauld for helpful discussions; NIAMDD and Dr M. Jutisz for hormone preparations; and Dr S. Lynch for the M91 antiserum.

\section{References}

Baird, D.T. \& McNeilly, A.S. (1981) Gonadotrophic control of follicular development and function during the oestrous cycle of the ewe. J. Reprod. Fert., Suppl. 30, 119-133.

Bindon, B.M. \& Piper, L.R. (1982) Physiological characteristics of high fecundity in sheep and cattle. Proc. Wld Congr. Sheep and Beef Cattle Breeding, Massey Univ., pp. 315-331. Palmerston North, New Zealand.

Brown, J.M., Cumming, I.A., Goding, J.R. \& Hearnshaw, H. (1972) Control of baseline levels of luteinizing hormone in the ewe. J. Reprod. Fert. 28, 134-135.

Cahill, L.P., Saumande, J., Ravault, J.P., Blanc, M., Thimonier, J., Mariana, J.C. \& Mauléon, P. (1981) Hormonal and follicular relationships in ewes of high and low ovulation rate. J. Reprod. Fert. 62, 141-150.

Clarke, I.J. \& Cummins, J.T. (1982) The temporal relationship between gonadotropin releasing hormone (GnRH) and luteinizing hormone ( $\mathrm{LH})$ secretion in ovariectomized ewes. Endocrinology 111, 1737-1739.

Cummins, L.J., O'Shea, T., Bindon, B.M., Lee, V.W.K. \& Findlay, J.K. (1983) Ovarian inhibin content and sensitivity to inhibin in Booroola and control strain Merino ewes. J. Reprod. Fert. 67, 1-7.

Davis, I.F., Brien, F.D., Findlay, J.K. \& Cumming, I.A. (1981) Interactions between dietary protein, ovulation rate and follicle stimulating hormone level in the ewe. Anim. Reprod. Sci. 4, 19-28.

Fraser, H.M. \& McNeilly, A.S. (1983) Differential effects of LH-RH immunoneutralization on LH and FSH secretion in the ewe. J. Reprod. Fert. 69, 569577.

Garner, L.L. \& Blake, C.A. (1981) Ultrastructural, immunocytochemical study of the LH secreting cell of the rat anterior pituitary gland: changes occurring after ovariectomy. Biol. Reprod. 24, 461-474.

Goodman, R.L., Legan S.J., Ryan, K.D., Foster, D.L. \& Karsch, F.J. (1981a) Importance of variations in behavioural and feedback actions of oestradiol to the control of seasonal breeding in the ewe. J. Endocr. 89, 229-240.

Goodman, R.L., Pickover, S.M. \& Karsch, F.J. (1981b) Ovarian feedback control of follicle-stimulating hormone in the ewe: evidence for selective suppression. Endocrinology 108, 772-777.
Goodman, R.L., Bittman, E.L., Foster, D.L. \& Karsch, F.J. (1982) Alterations in the control of luteinizing hormone pulse frequency underlie the seasonal variation in estradiol negative feedback in the ewe. Biol. Reprod. 27, 580-589.

Karsch, F.J., Dierschke, D.J., Weick, R.F., Yamaji, T., Hotchkiss, J. \& Knobil, E. (1973) Positive and negative feedback control by estrogen of luteinizing hormone secretion in the rhesus monkey. Endocrinology 92, 799-804.

Karsch, F.J., Legan, S.J., Hauger, R.L. \& Foster, D.L. (1977) Negative feedback action of progesterone on tonic luteinizing hormone secretion in the ewe: dependence on the ovaries. Endocrinology 101, 800806.

Lahlou-Kassi, A., Schams, D. \& Glatzel, P. (1984) Plasma gonadotrophin concentrations during the oestrous cycle and after ovariectomy in two breeds of sheep with low and high fecundity. J. Reprod. Fert. 70, 165173.

Land, R.B. (1976) Sensitivity of the ovulation rate of Finnish Landrace and Blackface ewes to exogenous oestrogen. J. Reprod. Fert. 48, 217-218.

Land, R.B., Wheeler, A.G. \& Carr, W.R. (1976) Seasonal variation in the oestrogen induced LH discharge of ovariectomised Finnish Landrace and Scottish Blackface ewes. Annls Biol. anim. Biochim. Biophys. 16, 521-528.

Land, R.B., Carr, W.R., McNeilly, A.S. \& Preece, R.D. (1980) Plasma FSH, LH, the positive feedback of oestrogen, ovulation and luteal function in the ewe given bromocriptine to suppress prolactin during seasonal anoestrus. J. Reprod. Fert. 59, 73-78.

Land, R.B., Atkins, K.D. \& Roberts, R.C. (1983) Genetic improvements of reproductive performance. In Sheep Production, ch. 27, pp. 515-535. Ed. W. Haresign. Butterworths, London.

Legan, S.J. \& Karsch, F.J. (1979) Neuroendocrine regulation of the estrous cycle and seasonal breeding in the ewe. Biol. Reprod. 20, 74-85.

Legan, S.J. \& Karsch, F.J. (1980) Photoperiodic control of seasonal breeding in ewes: modulation of the negative feedback action of estradiol. Biol. Reprod. 23, 1061-1068.

Legan, S.J., Karsch, F.J. \& Foster, D.L. (1977) The endocrine control of seasonal reproductive function 
in the ewe: a marked change in response to the negative feedback action of estradiol on luteinizing hormone secrection. Endocrinology 101, 818-824.

Levine, J.E., Pan, K.Y.F., Ramirez, V.D. \& Jackson, G.L. (1982) Simultaneous measurement of luteinizing hormone-releasing hormone and luteinizing hormone release in unanesthetized, ovariectomized sheep. Endocrinology 111, 1449-1455.

Martensz, N.D., Baird, D.T., Scaramuzzi, R.J. \& Van Look, P.F.A. (1976) Androstenedione and the control of luteinizing hormone in the ewe during anoestrus. $J$. Endocr. 69, 227-237.

McNeilly, J.R., McNeilly, A.S., Walton, J.S. \& Cunningham, F.J. (1976) Development and application of a heterologous radioimmunoassay for ovine folliclestimulating hormone. J. Endocr. 70, 69-79.

Miller, K.F., Critser, J.K. \& Ginther, O.J. (1982) Inhibition and subsequent rebound of FSH secretion following treatment with bovine follicular fluid in the ewe. Theriogenology 18, 45-53.

Platt, T.E., Foster, G.S., Tamavsky, G.K. \& Reeves, J.J. (1983) Effects of photoperiod and estradiol on tonic gonadotropins in ovariectomized ewes. J. Anim. Sci. 56, $1180-1185$.

Rodbard, D. \& Lewald, J.G. (1970) Computer analysis of radioligand assay and radioimmunoassay data. Acta endocr., Copenh., Suppl. 147, 79-103.
Scaramuzzi, R.J. \& Baird, D.T. (1977) Pulsatile release of luteinizing hormonc and the secretion of ovarian steroids in sheep during anestrus. Endocrinology 101, 1801-1806.

Scheffé, H. (1959) The Analysis of Variance. Wiley, New York.

Webb, R. \& England, B.G. (1982) Identification of the ovulatory follicle in the ewe: associated changes in follicle size, thecal and granulosa cell luteinizing hormone receptors, antral fluid steroids and circulating hormones during the preovulatory period. Endocrinology 110, 873-881.

Webb, R. \& Gauld, I.K. (1984) Folliculogenesis in sheep: control of ovulation rate. In Genetics of Sheep Reproduction, ch. 26, pp. 261-274. Eds R. B. Land \& D. W. Robinson. Butterworths, London.

Wright, P.J., Findlay, J.K. \& Anderson, G.A. (1981) The failure of prolactin to enhance the inhibitory effect of oestradiol-17ß on LH synthesis and release in ewes. $J$. Reprod. Fert. 62, 537-542.

Wright, P.J., Steimasial, T. \& Anderson, G.A. (1983) Suppressed release of $\mathrm{LH}$ in ovariectomized postpartum ewes. J. Reprod. Fert. 67, 197-202.

Received 8 June 1984 